\title{
Timing, togetherness and time windfalls
}

\author{
Daniel S. Hamermesh \\ Department of Economics, University of Texas, Austin, TX 78712-1173 USA \\ (Fax: +1-512-471-3510; e-mail: hamermes@eco.utexas.edu)
}

Received: 6 July 2000/Accepted: 20 January 2001

\begin{abstract}
With appropriate data the analysis of time use, labor supply and leisure can move beyond the standard questions of wage and income elasticities of hours supplied. I present four examples: 1) American data from 1973 through 1997 show that the amount of evening and night work in the U.S. has decreased. 2) The same data demonstrate that workers whose relative earnings increase experience a relative diminution of the burden of work at unpleasant times. 3) U.S. data for the 1970s and 1990s demonstrate that spouses' work schedules are more synchronized than would occur randomly; synchrony among working spouses diminished after the 1970s; and the full-income elasticity of demand for it was higher among wives than among husbands in the 1970s but equal in the 1990s. 4) Dutch time-budget data for 1990 show that the overwhelming majority of the windfall hour that occurred when standard time resumed was used for extra sleep.
\end{abstract}

JEL classification: J20

Key words: Leisure, time use, work amenities

\section{Introduction}

For many years labor supply has been the single most heavily researched topic in the subfield of labor economics (Stafford, 1986). Nearly all of this research

Daniel S. Hamermesh is Edward Everett Hale Centennial Professor, University of Texas at Austin; research associate, National Bureau of Economic Research, and Forschungsinstitut zur Zukunft der Arbeit. I thank the National Science Foundation for support under Grants SBR-9422429 and SES-9904699, and two anonymous referees, Gerard Pfann, the late Lee Lillard, Gerald Oettinger, Steve Trejo and participants at the ESPE Conference and at seminars at the University of Bristol and Warwick University for helpful comments. Responsible editor: Klaus F. Zimmermann. 
has been based on data derived from questions about how many hours, weeks or years people have been engaged in market-based activities. The focus has been on the integration of workers' time to derive the fraction of some particular interval that is spent in market work. Very little research has examined time use - how individuals spend their time at work and in other activities; and almost none has examined the economic implications of when people engage in work and nonwork activities.

These little-studied supply-related topics can provide insights into a variety of questions that have been addressed in other ways, and often not so successfully, using more standard approaches and more commonly used data. For examples, changes in the distribution of workers' well-being depend not only on the monetary returns to work, but also on the changing distribution of such nonmonetary returns as the timing of work. The issue of jointness in a married couple's supply of labor can only be addressed if we know when the couple is working. Simply examining how the total of one spouse's hours affects the other's is not informative about their decisions on supplying labor as affected by what is presumably their desire to be together, or by their possible need for childcare. As still another example, there is an immense literature attempting to estimate pure income effects on labor supply. Yet equally important, and for obvious reasons essentially unstudied, is the pure full-income effect of an increase in available time.

The purpose in this study is not to provide a definitive list of new ways of viewing time use that might be generally interesting to economists and to labor economists/demographers especially. Rather, it is to give what I believe are some novel and interesting examples that I hope might inspire others to approach these and similarly motivated issues using the many underutilized sets of data that are available for this purpose. This is a much more fruitful endeavor than the development of ever more complex econometric models of labor supply that focus on the same standard questions of measuring wage and income effects on hours/weeks worked using standard data sets. I hope to demonstrate that moving beyond refinements to the standard model and its estimation can be useful and interesting.

Accordingly, in Sect. 2 I examine the role of work timing - when people work - as an amenity of the employment relation and consider how changes in timing in the United States might be taken as reflecting changes in the wellbeing of the average worker. Section 3 uses this same idea to consider how our understanding of labor-market inequality is altered when we take nonmonetary characteristics of work, in this case the timing of work, into consideration. In Sect. 4 I study the demand for work timing in the context of the household, focusing particularly on whether spouses" "togetherness" is affected by their incomes and how this demand has changed over time. Section 5 focuses on examining responses to an exogenous increase in the time at their disposal by a random sample of households. These ideas and empirical analyses are tied together by the common themes that they illustrate new ways of thinking about labor supply and leisure and that they test how shocks to the economy alter outcomes along a variety of dimensions of time use and the timing of activities.

\section{Work timing as a workplace amenity}

The argumentation here and in the rest of the study compares outcomes across equilibria in the labor market. Unsurprisingly, very little can be inferred out- 
side of equilibrium, especially if the burden of the disequilibria varies across workers. The value of this standard, neoclassical approach lies in its predictive ability, so that the contribution of these analyses must be measured by whether the facts that are uncovered accord with the theory that is outlined.

It is easy to see how changes in amenities are altered when the real earnings capacities of workers in different groups change. View workers as being able to obtain a combination of real earnings, other monetary benefits (which I henceforth subsume under earnings), and nonmonetary benefits from the jobs they occupy (as originally in Rosen 1974). Workers sort themselves among jobs that differ by the amenities that the jobs offer according to their preferences for nonmonetary amenities and earnings. Workers who especially prefer amenities (e.g., are extremely averse to working at night) will sort into jobs that avoid night work. Jobs that fail to offer the amenity of day work must compensate for its absence through higher wages in order to attract workers. We will observe that otherwise identical workers obtain higher wages in those jobs, so that they may be viewed as offering premium wages (see Kostiuk 1990, for evidence on this). Because workers whose overall earnings ability is low require earnings just to get by, they will be especially willing to accept unpleasant jobs that compensate for the unpleasantness by offering higher wages.

What will happen in such a labor market as full earnings rise generally? We will observe ever-fewer workers who are willing to accept work at undesirable times. This will induce employers to: 1) Offer higher premia to attract workers to such times; but 2) Price out of the market some employers who would otherwise have conducted their business at evening/night. We should observe the price (compensating wage differential) for such work rising, while the quantity of such work falls. Indeed, if we are uncertain about the path of real earnings (perhaps, as in the United States, because of difficulties measuring indexes of living costs, Boskin et al. 1998), a good indication that real earnings have risen is that the quantity of disamenities observed in the labor market, including work at undesirable times, has fallen (barring major changes in legal restrictions on the provision of amenities/disamenities, none of which occurred in the United States during this period).

This entire discussion is from the supply side of the labor market and entirely ignores the effects of possible shocks to employers' labor demand. If technical change makes evening/night work more expensive for employers at a given set of supply conditions, we would observe a decline in the quantity of such work performed even though workers' full earnings have not risen. While this is possible and is extremely difficult to contradict, most observers of the labor market argue that technology has shifted people toward a 24-hour economy, implying that the bias in technology has been toward an increase in the demand for evening/night work, other things equal. Thus if we find despite this that the amount of evening/night work has declined, we can reasonably assume that supply behavior has dominated this implicit market.

To illustrate this approach I take data from the United States Current Population Survey May Supplements for 1973, 1978, 1985, 1991 and 1997 (the earliest four of which are also used for a related purpose in Hamermesh 1999a). In these few surveys (and in the May Supplements from 1974 through 1977) respondents were questioned about the starting and ending times on their main jobs: "At what time of day did ... begin (end) work on this job most days last week?" Regrettably the questions are not specific to each day of the week, but rather talk about what the worker "usually" does. The ideal, a set of repeated 
cross-sections of large numbers of time diaries showing exactly when people are at work for each of a number of days, is simply unavailable in the United States or elsewhere. To ensure that the workers in the sample are at work at these hours on most days, only employees with at least 20 hours of work per week are included in the analysis in this section.

From the information the respondents provided I can construct a set of 24 indicators, $L_{i s t}$, for each worker $i$ interviewed in year $t$, with the indicator equaling 1 if the responses imply that the person worked in the market at hour $s, 0$ if not. This is different from identifying workers as being on shifts, as has been done by, for example, Mellor (1986). Because a majority of workers on the job at, for example, 3AM would not be classified as night-shift workers (Hamermesh 1996), this hour-by-hour approach gives a fuller picture of the distribution of work.

Before examining how the distribution has changed, we need to establish whether in fact there is a consistent pattern relating work at various times of the day to workers' demographic characteristics. To save space I define the variables $E V E=1$ if the worker was on the job at any time between 7PM and 10PM, 0 otherwise, and $N I G H T=1$ if he/she was on the job at any time between $10 \mathrm{PM}$ and $6 \mathrm{AM}, 0$ otherwise. I relate these variables to workers' educational attainment, their age, ethnic/racial status and other controls available in the CPS. In addition, in the some of the estimates I hold constant for the workers' detailed industry affiliation (thus controlling for potential differences caused by employers' rather than the workers' behavior).

The top row of Table 1 presents for both genders the mean fractions of employees working evenings or nights. Unsurprisingly, men are more likely to be working during these unusual hours than are women. Below these means the Table lists the coefficients from linear-probability estimates of the determinants of EVE and NIGHT for all workers in the May 1997 Supplement whose usual weekly hours were 20 or more. (Probits yield qualitatively similar conclusions.) For both $E V E$ and NIGHT the first column in each pair presents estimates that exclude industry indicators, while the second includes them. The results make it very clear that evening or night work disproportionately burdens those with lower educational attainment (since the excluded category is workers with less than a high-school diploma). Similarly, the U-shaped relationship between age and the incidence of evening or night work shows that such labor is disproportionately done by younger workers or those nearing retirement. Holding constant their total workhours, the lowest probability of work outside the standard workday is among workers around age 50, roughly the peak of age-earnings profiles. This negative relationship between the probability of working evening or night and a worker's earnings ability is changed only slightly even when we account for the worker's detailed industry affiliation.

The estimates in Table 1 also provide some evidence that evening and night work is performed disproportionately by minorities, especially by AfricanAmericans, even after accounting for racial/ethnic differences in age and educational attainment. There are essentially no differences in the probabilities of evening and night work between nonhispanic whites (the excluded category) and Hispanics. The differences in the probabilities of working evenings/nights are consistent with the notion that workers whom the labor market rewards less are more likely to work evenings or nights. By inference, evening/night work is a disamenity. 
Table 1. Means and regression estimates of the determinants of evening and night work, May 1997 CPS $^{\mathrm{a}}$

\begin{tabular}{|c|c|c|c|c|c|c|c|c|}
\hline \multirow[t]{3}{*}{ Work in: } & \multicolumn{4}{|c|}{ Men } & \multicolumn{4}{|c|}{ Women } \\
\hline & \multicolumn{2}{|l|}{ Evening } & \multicolumn{2}{|l|}{ Night } & \multicolumn{2}{|l|}{ Evening } & \multicolumn{2}{|l|}{ Night } \\
\hline & (1) & (2) & (3) & (4) & $(5)$ & (6) & (7) & (8) \\
\hline $\begin{array}{l}\text { Fraction } \\
\text { working: }\end{array}$ & \multicolumn{2}{|c|}{0.168} & \multicolumn{2}{|c|}{0.117} & \multicolumn{2}{|c|}{0.129} & \multicolumn{2}{|c|}{0.079} \\
\hline HS grad & $\begin{array}{r}-0.036 \\
(0.009)\end{array}$ & $\begin{array}{r}-0.027 \\
(0.008)\end{array}$ & $\begin{array}{c}0.004 \\
(0.007)\end{array}$ & $\begin{array}{r}-0.001 \\
(0.007)\end{array}$ & $\begin{array}{r}-0.123 \\
(0.009)\end{array}$ & $\begin{array}{r}-0.085 \\
(0.009)\end{array}$ & $\begin{array}{r}-0.046 \\
(0.007)\end{array}$ & $\begin{array}{r}-0.023 \\
(0.007)\end{array}$ \\
\hline $\begin{array}{l}\text { Some } \\
\text { college }\end{array}$ & $\begin{array}{c}-0.022 \\
(0.009)\end{array}$ & $\begin{array}{c}-0.023 \\
(0.009)\end{array}$ & $\begin{array}{c}-0.004 \\
(0.008)\end{array}$ & $\begin{array}{c}-0.012 \\
(0.008)\end{array}$ & $\begin{array}{c}-0.123 \\
(0.009)\end{array}$ & $\begin{array}{r}-0.076 \\
(0.009)\end{array}$ & $\begin{array}{c}-0.055 \\
(0.007)\end{array}$ & $\begin{array}{c}-0.028 \\
(0.007)\end{array}$ \\
\hline $\begin{array}{l}\text { College } \\
\text { degree }\end{array}$ & $\begin{array}{r}-0.082 \\
(0.009)\end{array}$ & $\begin{array}{r}-0.080 \\
(0.009)\end{array}$ & $\begin{array}{r}-0.089 \\
(0.008)\end{array}$ & $\begin{array}{r}-0.086 \\
(0.008)\end{array}$ & $\begin{array}{r}-0.159 \\
(0.009)\end{array}$ & $\begin{array}{r}-0.096 \\
(0.010)\end{array}$ & $\begin{array}{r}-0.095 \\
(0.007)\end{array}$ & $\begin{array}{r}-0.062 \\
(0.008)\end{array}$ \\
\hline Age & $\begin{array}{r}-0.023 \\
(0.001)\end{array}$ & $\begin{array}{r}-0.017 \\
(0.001)\end{array}$ & $\begin{array}{r}-0.005 \\
(0.001)\end{array}$ & $\begin{array}{c}-0.005 \\
(0.001)\end{array}$ & $\begin{array}{r}-0.024 \\
(0.001)\end{array}$ & $\begin{array}{r}-0.020 \\
(0.001)\end{array}$ & $\begin{array}{r}-0.006 \\
(0.001)\end{array}$ & $\begin{array}{r}-0.006 \\
(0.001)\end{array}$ \\
\hline $\mathrm{Age}^{2} / 100$ & $\begin{array}{c}0.024 \\
(0.001)\end{array}$ & $\begin{array}{c}0.018 \\
(0.001)\end{array}$ & $\begin{array}{c}0.005 \\
(0.001)\end{array}$ & $\begin{array}{c}0.005 \\
(0.001)\end{array}$ & $\begin{array}{c}0.025 \\
(0.001)\end{array}$ & $\begin{array}{c}0.021 \\
(0.001)\end{array}$ & $\begin{array}{c}0.006 \\
(0.001)\end{array}$ & $\begin{array}{c}0.006 \\
(0.001)\end{array}$ \\
\hline $\begin{array}{l}\text { African- } \\
\text { American }\end{array}$ & $\begin{array}{c}0.032 \\
(0.010)\end{array}$ & $\begin{array}{c}0.012 \\
(0.009)\end{array}$ & $\begin{array}{c}0.053 \\
(0.008)\end{array}$ & $\begin{array}{c}0.021 \\
(0.008)\end{array}$ & $\begin{array}{c}0.023 \\
(0.008)\end{array}$ & $\begin{array}{c}0.024 \\
(0.007)\end{array}$ & $\begin{array}{c}0.033 \\
(0.006)\end{array}$ & $\begin{array}{l}0.026 \\
(0.006)\end{array}$ \\
\hline Hispanic & $\begin{array}{c}0.003 \\
(0.009)\end{array}$ & $\begin{array}{r}-0.005 \\
(0.009)\end{array}$ & $\begin{array}{c}0.004 \\
(0.008)\end{array}$ & $\begin{array}{r}-0.001 \\
(0.008)\end{array}$ & $\begin{array}{r}-0.009 \\
(0.009)\end{array}$ & $\begin{array}{r}-0.001 \\
(0.009)\end{array}$ & $\begin{array}{c}0.008 \\
(0.007)\end{array}$ & $\begin{array}{c}0.009 \\
(0.007)\end{array}$ \\
\hline $\begin{array}{l}\text { Industry } \\
\text { controls: }\end{array}$ & No & Yes & No & Yes & No & Yes & No & Yes \\
\hline$R^{2}$ & 0.140 & 0.232 & 0.130 & 0.215 & 0.148 & 0.217 & 0.206 & 0.247 \\
\hline$N$ & \multicolumn{4}{|c|}{19520} & \multicolumn{4}{|c|}{17402} \\
\hline
\end{tabular}

a The equations also control for marital status, geographic location and total hours worked. Standard errors are in parentheses below the parameters estimates here and in Tables 2, 4-6.

For each hour of the day in each year $t$ for which the data are available I calculate:

$$
\Delta F_{s t}=F_{s t}-F_{s 73}, \quad t=1978,1985,1991,1997,
$$

where $F_{s t}$ is the fraction of employees at work at hour $s$ in year $t$, adjusted so that the average daily hours worked are unchanged over the time period. These differences thus summarize what happened to work timing in the United States in the final quarter of the twentieth century. Figures $1 \mathrm{a}$ and $1 \mathrm{~b}$ use these CPS Supplements to present for male and female workers the fractions that were at work at each hour of the day. (The patterns look quite similar if the few employees working less than 20 hours per work are added to the samples.) To get a feel for the magnitude of these changes, one should note that in 1973 the fraction of men at work at Noon was 0.88 , while the fraction working at $3 \mathrm{AM}$ was 0.09 . The fractions for women were slightly lower.

The figures show very clearly that the trend was toward less work being performed by men in the evening and at night, and some of these drops are substantial. For example, the drop of over 0.02 at $3 \mathrm{AM}$ represents a decline of over $30 \%$ (and of over five standard errors in these samples). In percentage terms the 0.07 rise in the fraction of men at work at 7AM is smaller (around 20\%), but it is clear that more work is being accomplished in the early morning hours. The decline in evening and night work did not occur between 1973 and 1978, a time 

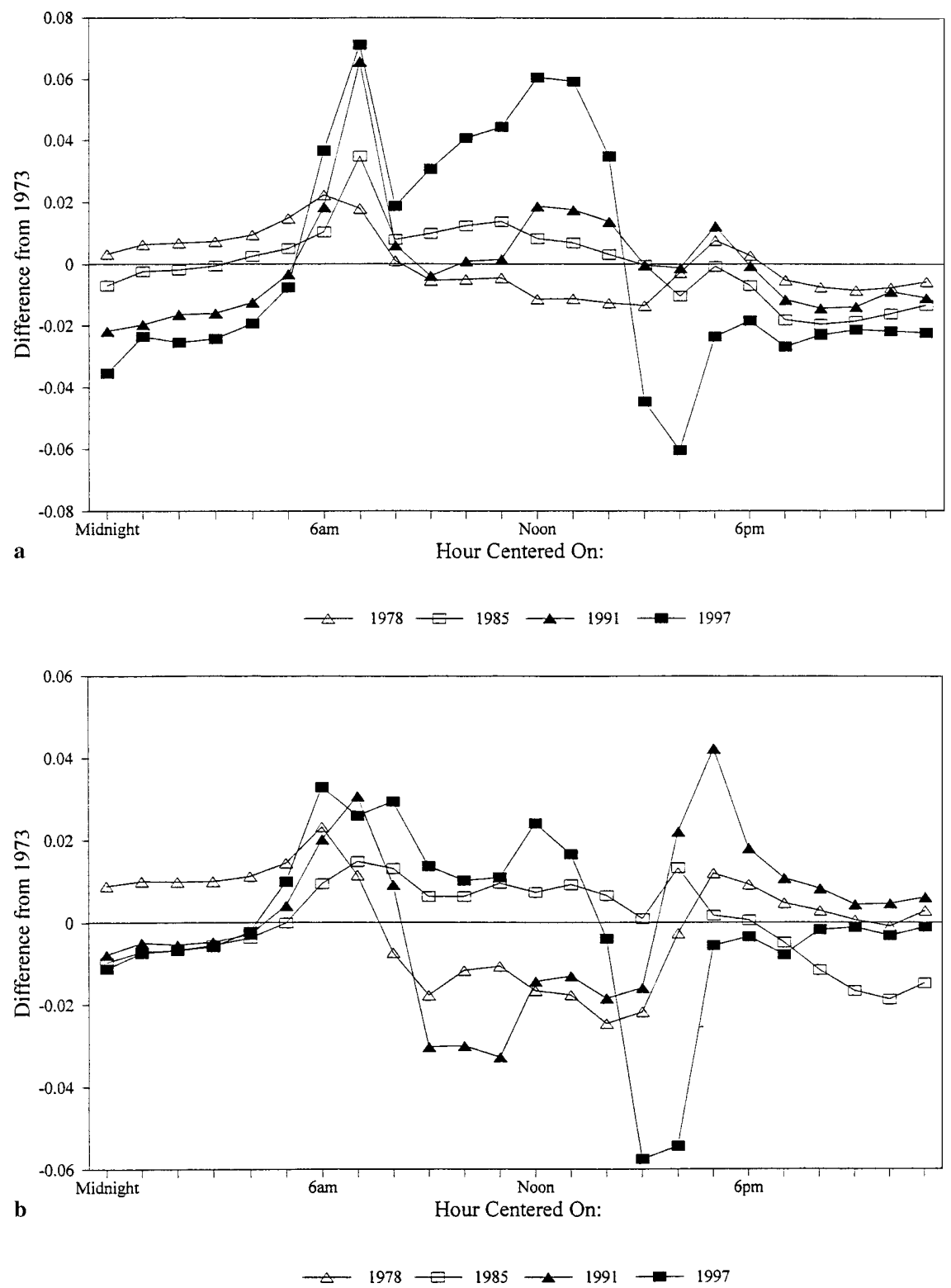

Fig. 1a,b. Differences over 1973 in fraction working. a Men; b Women

when it is quite clear that real earnings in the U.S. failed to increase; but it is fairly steady thereafter. This decline is fully consistent with rising full earnings. ${ }^{1}$

Among women the changes are less pronounced, with significant declines being observed in evening but not in night work. With women's wages surely increasing over this period relative to men's this one deviation in the results may be disturbing. One should remember, however, that the kinds of industries and occupations where technological change may have been most heavily 
biased toward night work are those that are especially female-intensive, particularly service and retail industries. Those occupations/industries may be sufficient in number that the bias of technology toward night work is sufficient to have outweighed the induced reduction in supply of night-time labor.

The main point of this section is that, almost certainly contrary to popular belief, the best evidence suggests that evening/night work in the United States has diminished in importance since the early 1970s. As shown in Hamermesh (1999a, Fig. 3), evening and night work among all workers decreased through 1991 among men in all major industries except the tiny (in the United States) agriculture sector. The same is true for evening work in all major industries among women. This is consistent with the view that workers' real earning power has increased and that they have used part of it to shift away from work at an unpleasant time. Whether this is true universally is unclear; but the approach taken here should be applicable in other economies. Examining secular changes in other labor economies would be a useful approach to understanding the changing well-being of their workers.

\section{Work timing and economic inequality}

In the past 20 years, whether because of increased international trade (Leamer 1996), technical change that is biased toward skilled workers (Berman et al. 1998), declines in institutions that protect low-skilled workers, or still other causes, shocks to the labor market have raised the earnings ability of skilled workers relative to unskilled workers essentially worldwide (Pereira and Martins 2000). These changes have implied a relative improvement in the prospects of those who would have earned more even without them. This should have caused those workers, even more than before, to shy away from jobs that lack such workplace amenities as desirable schedules, since their earning power has increased most. Obversely, low-skilled workers will be observed occupying an even greater fraction of the jobs that have undesirable characteristics: Because the supply of skilled workers to those jobs is reduced, employers offering them will pay higher wage premiums; and, with their earnings ability falling relative to other workers, the relative supply of lower-skilled workers to jobs offering these premiums will be higher than before.

Changes in the distribution of workplace amenities should thus mirror changes in the distribution of wages. We would expect that the widening distribution of earnings would have been accompanied by an increasingly unequal distribution of the burden of unpleasant workplace characteristics. This will be true so long as employers' ability to offer daytime jobs has not changed differentially by the skill of its workers. In other words, only skill-biased technical change in the provision of the amenity, working during the day, will cause this prediction to fail.

While it is clear that sorting in the changing implicit market for the amenity of desirable work timing will cause a change in the distribution of the amenity, the implications for inequality of full earnings - wages plus the value of the amenity - are unclear. Write full earnings $E$ in logarithmic form as:

$$
E=W+\theta D,
$$

where $\theta$ is the premium for evening/night work, and $D$ equals 1 if the worker 
works evenings/nights. Imagine a shock to the labor market that increases the variance of full earnings. Assume that the full-income elasticity of demand for the amenity exceeds unity by enough to offset the rise in $\theta$ (an assumption that is consistent with evidence showing very high income elasticities of demand for monetary benefits, Woodbury and Hamermesh 1992). We will then observe that an increase in the variance of log-wages $(W)$ will be accompanied by an increase in the variance of $E$.

Having shown that workers with lower earnings potential have a greater likelihood of performing evening/night work, we can examine how patterns of work timing have changed in relation to changing earnings differences. As in the literature on earnings inequality (Juhn et al. 1993), I base the comparisons on the weekly earnings of full-time (35+ hours per week) workers. To verify that the earnings of full-time workers in these May CPS Supplements exhibit the same rise in inequality that has been noted more generally, Fig. 2 presents estimates of:

$$
\begin{aligned}
\Delta^{2} W_{t}^{q} & =\left[W_{t}^{q}-W_{t}^{4}\right]-\left[W_{73}^{q}-W_{73}^{4}\right] \\
q & =1,2,3, \quad t=1978,1985,1991,1997,
\end{aligned}
$$

where $W$ is the logarithm of average weekly earnings among workers in earnings quartile $q$ in year $t$, and the superscript 4 refers to workers in the bottom quartile of earnings. ${ }^{2}$ The measures $\Delta^{2} W_{t}^{q}$ for men and women thus show percentage changes in average earnings within each of the three upper quartiles since 1973 compared to percentage changes in earnings in the lowest quartile.

The estimates of these double-differences in earnings are shown in Figs. 2a and $2 \mathrm{~b}$ for men and women. The results parallel what has been demonstrated generally for the United States over this period. For both genders there has been a very sharp rise in earnings inequality since the early 1970s, with much of the increase coming between 1978 and 1985. The biggest relative increases have been in the top earnings quartile, with increases generally being somewhat larger among men than women. Similar patterns to these, and to the remaining results in this section, are shown if we disaggregate the full-time workforce by earnings decile.

The data are sorted by weekly earnings, and for each worker the fraction of his/her total workday accounted for by work at each hour $s$ is calculated. These data were then averaged to give $f_{s t}^{q}$, the fraction of all work by those in the $q$ 'th earnings quartile in year $t$ that was performed at hour $s$. The measure $f$ indicates the intensity of work at each hour by the average full-time worker in the earnings quartile. Relative changes since 1973, and thus in the burden of work at each hour of the day, can be summarized by the differences

$$
\Delta^{2} f_{s t}^{q}=\left[f_{s t}^{q} / f_{s t}^{4}\right]-\left[f_{s 73}^{q} / f_{s 73}^{4}\right]
$$

calculated as ratios to allow for convenient presentation. A ratio below one implies that workers in quartile $q$ performed a smaller fraction of their total hours of work at hour $s$ than did workers in the lowest earnings quartile. A negative difference means that since 1973 workers in quartile $q$ became relatively less likely than workers in the bottom earnings quartile to work at time $s$.

Figure $3 \mathrm{a}$ shows these interquartile differences for men, while Fig. 3b presents the same information for women. To save space only the differences be- 

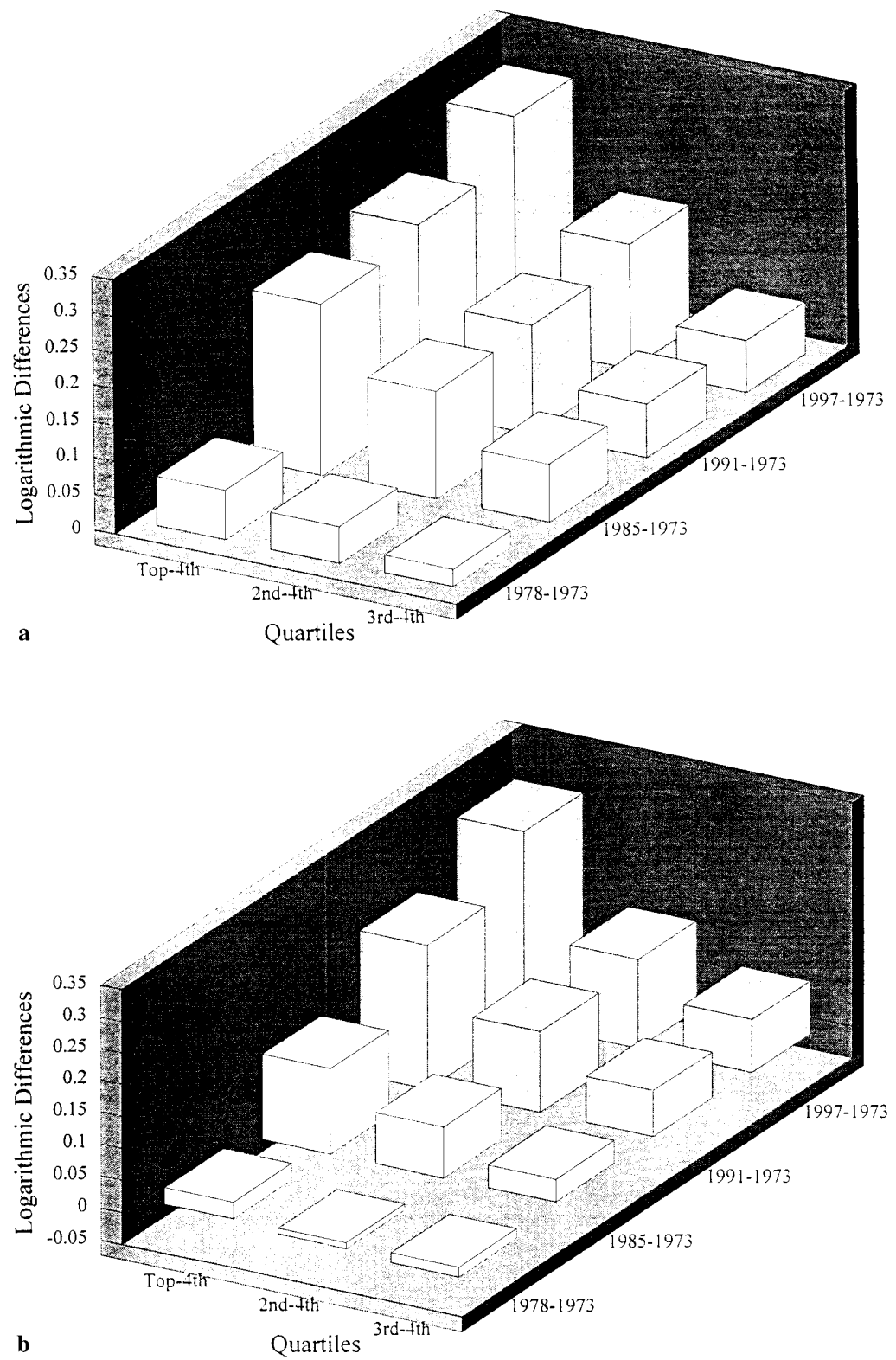

Fig. 2a,b. Double differences in weekly earnings. a Men 1973-1997; b Women 1973-1997

tween workers in the top and bottom earnings quartiles are shown. The results for workers in the second quartile (percentiles 75 to 50) look similar, while there are no major changes in timing between workers in the third and bottom quartiles (which is not surprising given the small relative changes in earnings shown in Fig. 2). While the differences are small in 1978, beginning in 1985 they started to depart from zero. In particular, for both men and women there 

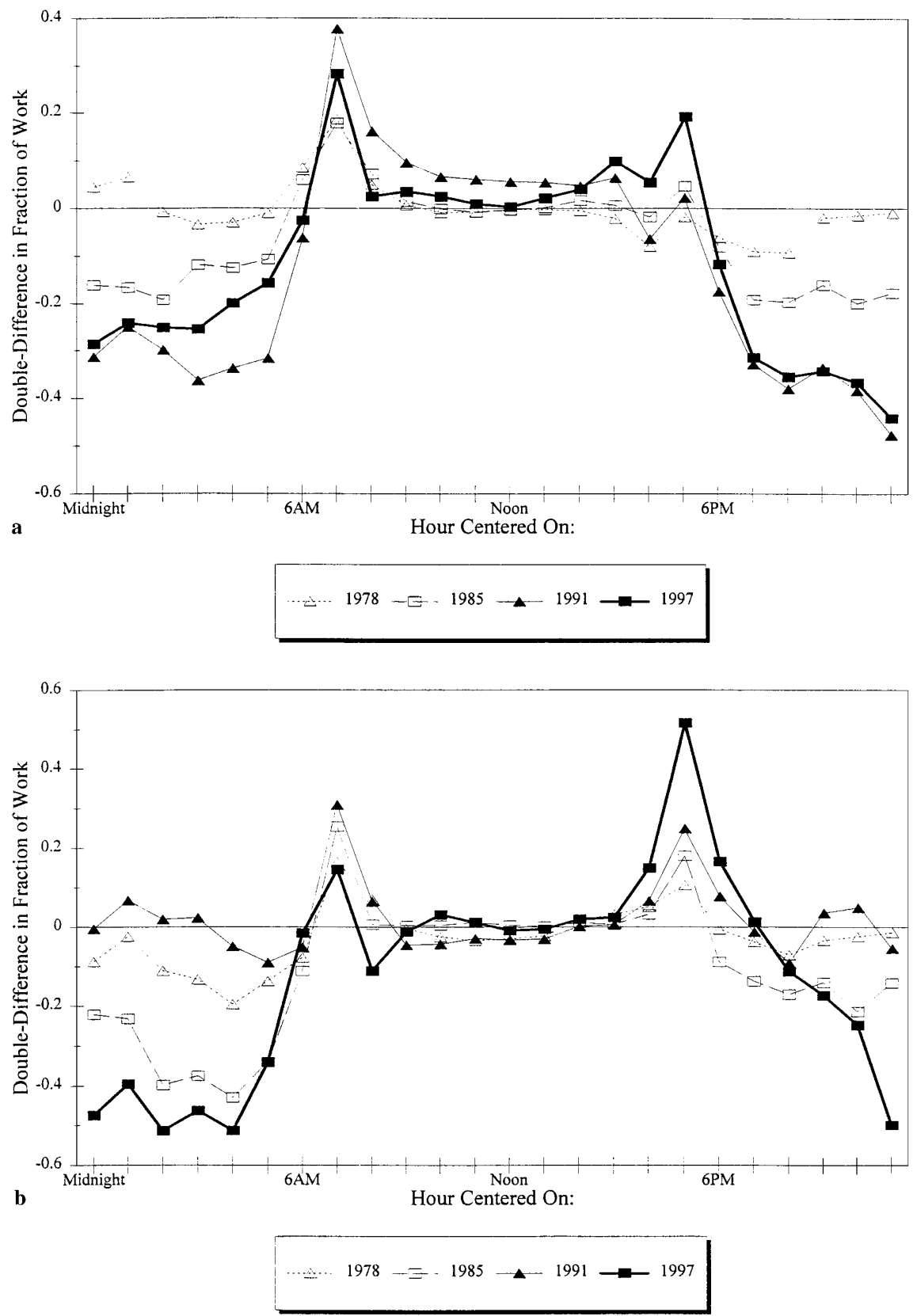

Fig. 3a,b. Top-bottom quartile differences in work timing over 1973. a Men; b Women

was a general, albeit unsteady decrease in the differences in the evening and night hours. The negative values of $\Delta^{2} f_{s t}^{1}$ between 8PM and 5AM show that the relative burden of evening and night work was increasingly borne over this quarter-century by workers in the bottom quartile of the earnings distribution. 
The negative values of $\Delta^{2} f_{s t}^{1}$ between 8PM and 5AM must be offset by positive values at other times. These offsets occur especially at the fringes of the "normal" workday. Implicitly, higher-wage workers, whose total workhours have been increasing (see Juhn et al. 1991), have been spreading their workdays to early morning and late afternoon, at the same time that they have been cutting back from working in the evenings and at night (at least compared to lower-wage workers). The double differences for 1997 are quite similar for men and women; but for women the decline in evening/night work and the rise in work at the edges of the regular workday do not exhibit the same steady trend that they do among men. Since similar steady changes exist for men by major industry, but not for women, this gender difference is not a reflection of the sexes' different representations by industry.

I have demonstrated that there has been a relative decline in work at undesirable times of the day among precisely those workers whose earnings have risen relatively. To infer the strength of the relationship between changes in the incidence of evening and night work and changes in relative earnings I estimate:

$$
F_{s t}^{q}-F_{s t}^{4}=a+b\left[W_{t}^{q}-W_{t}^{4}\right], \quad s=1, \ldots, 24,
$$

where, as in Section 2, $F$ is the fraction of employees in earnings quartile $q$ who are at work at hour $s$ in year $t$. Also included in the estimation is a pair of indicator variables for quartiles 1 and 2. Each regression is based on 15 observations, since each pools three differences (earnings quartiles 1, 2 and 3 compared to quartile 4) for each of the five years 1973, 1978, ., 1997. Each is estimated over each hour $s$ for men and women separately. They indicate a relationship between changes in earnings and changes in work timing, not causation: Both work timing and earnings are outcomes that are generated by a combination of workplace technologies and workers' earnings capacities and preferences.

The estimates of the slope parameters in (5) are shown for selected hours $s$ in Table 2 . They make it fairly clear that, as interquartile earnings differences have increased, in the upper earnings quartiles the probabilities of working at odd hours have decreased relative to those of workers in the lowest earnings quartiles. This is especially apparent for men (among whom interquartile earnings differences rose more rapidly than among women). Obversely, the relative probabilities of working during regular daytime hours have increased along with increases in interquartile differences in earnings.

The comparisons show clearly that widening earnings inequality has been associated with lower-wage workers bearing an increasing share of the burden of work at these times. I have explained this in terms of workers' choices of jobs and occupations. One might instead argue that it has become relatively easier for employers to schedule higher-skilled workers' jobs outside of evenings and nights. This explanation is inconsistent with the common observation that it is higher-paid managerial and clerical workers who must work unusual hours to remain part of the Internet-wired global economy. It is also inconsistent with the facts: Figures like Figures 3 calculated for managerial and clerical workers alone show the same increasing relative burden of evening/night work on lowwage workers as do graphs based only on blue-collar workers.

While it is clear that the distribution of the amenity, desirable work timing, has widened in the same direction as the distribution of earnings, it is unclear whether the distribution of full earnings has also widened - whether, as dis- 
Table 2. The relation between interquartile differences in the fraction at work and interquartile differences in earnings, May CPS 1973, 1978, 1985, 1991, 1997

\begin{tabular}{lcc}
\hline Work at: & Men & Women \\
& $(1)$ & $(2)$ \\
\hline \multirow{2}{*}{ Midnight } & -0.105 & -0.071 \\
& $(0.031)$ & $(0.041)$ \\
3AM & -0.062 & -0.033 \\
& $(0.021)$ & $(0.037)$ \\
6AM & -0.014 & 0.016 \\
& $(0.036)$ & $(0.043)$ \\
9AM & 0.334 & 0.085 \\
& $(0.083)$ & $(0.042)$ \\
Noon & 0.241 & 0.209 \\
& $(0.059)$ & $(0.061)$ \\
3PM & 0.357 & 0.188 \\
& $(0.106)$ & $(0.068)$ \\
6 PM & -0.089 & 0.081 \\
& $(0.046)$ & $(0.060)$ \\
9PM & -0.221 & 0.069 \\
& $(0.037)$ & $(0.036)$ \\
\hline
\end{tabular}

cussed above, the amenity is a luxury good. Under certain very restrictive assumptions about homotheticity of workers' preferences and employers' profit functions, the full-earnings elasticities of demand for desirable work timing far exceed unity (Hamermesh 1999b). This is consistent with evidence on the demand for monetary nonwage job characteristics such as pensions and health care (e.g., Woodbury and Hamermesh 1992). We can be quite sure that the distribution of the amenity has widened substantially in the U.S.: The burden of working at bad times has increasingly been borne by low-skilled workers. We cannot, however, be sure that price changes in this amenity have been sufficiently small to ensure that the distribution of full earnings (including this amenity) has widened more in percentage terms than the distribution of earnings.

\section{Joint decision-making about the timing of leisure}

The jointness of spouses' work/leisure choices cannot be inferred by concentrating on the quantities that they consume over some interval of time. Given the relatively small fractions of the week that people in developed economies typically work in the market, we could very easily find that husbands' longer weekly hours are associated with wives' longer weekly hours, holding their wage rates constant, although each one is at home while the other works. Understanding the extent of jointness in time use requires analyzing when each spouse works in the market, i.e., the extent of overlap in the spouses' use of time. A couple can consume more leisure jointly when the number of hours that both spouses are at home is greater, not when the partial correlations of their total work times are higher.

In order to analyze the instantaneous jointness of spouses' decision-making, we need to specify the household's utility in arguments defined over points in 
time. Let the basic unit of time be the day, divided arbitrarily into 24 hours. Then we can write the household's maximand as:

$$
\begin{aligned}
& V\left(U^{M}\left(\left[1-L_{1}^{M}\right], \ldots,\left[1-L_{24}^{M}\right]\right)\right), U^{F}\left(\left[1-L_{1}^{F}\right], \ldots,\left[1-L_{24}^{F}\right]\right), \\
& \left.U^{J}\left(Z_{1}^{J}, \ldots, Z_{24}^{J}\right), C\right),
\end{aligned}
$$

where $Z_{s}^{J}=\left[1-L_{s}^{M}\right]\left[1-L_{s}^{F}\right], C$ is the household's consumption, and $M$ and $F$ denote the husband and wife respectively. The household's monetary gains are implicitly spent entirely on the one composite (household) public good. I also assume that each hour is indivisible, with the individual either working the entire hour or enjoying leisure. Equation (6) is maximized subject to the spending constraint:

$$
C=\sum_{s}\left[w_{s}^{M} L_{s}^{M}+w_{s}^{F} L_{s}^{F}\right]
$$

where $w_{s}^{j}=w^{j}\left[1+\theta_{s}\right]$. Each spouse $j$ faces an exogenous wage rate that varies over $s$ around $w^{j}$ by a percentage $\theta_{s}$ that is determined by the market supply and demand for labor at hour $s$ and that faces all workers regardless of sex.

Maximizing (6) subject to (7) yields the couple's optimizing sequences of market work times, $\left\{L_{s}^{M}\right\}$ and $\left\{L_{s}^{F}\right\}$. If the sequences were integrated over the day, they would yield each spouse's daily hours supplied to the market, $H^{j}$. A spouse will be working at hour $s$ if $w_{s}^{j}>w_{s}^{j r}$, the spouse's reservation wage for working at that hour. These reservation wages vary over $s$ and may be determined jointly by the spouses' bargaining. The object of interest here is to infer whether or not the subfunction $U^{J} \equiv 0$, that is, whether the outcome of the spouses' bargaining reflects any interest they may have in being at home together, conditional on their working in the market for given numbers of hours. (Alternatively, one might observe that couples' behavior is joint but implies a preference for being apart.) Only through this approach can we examine whether consuming synchronous leisure matters to the couple.

To examine the possibility of jointness in the timing of potential leisure I combine all the available data from the May 1970s CPS Supplements into one data set, and combine the data from the 1991 and 1997 May Supplements into another. In each CPS Supplement I match husbands' and wives' records to create a record for the couple that generates the sequences $\left\{L_{s}^{M}\right\}$ and $\left\{L_{s}^{F}\right\}$ and uses them to create the sequences $Z_{s}^{J} \cdot{ }^{3}$ Any matched couple in which one spouse was age 60 or over was excluded from the sample, since the purpose is to focus on market work and its complement. Only couples with both spouses working are included in the samples, both to avoid problems with corner solutions to the maximization of (6) and because our definition of joint leisure is identically the inverse of the working spouse's market time if there is a nonworking spouse. The usual CPS controls are used; and for each spouse I measure total daily hours of market work using the sequence $\left\{L_{s}^{j}\right\}$ and infer full hourly earnings using usual weekly earnings.

Whether the spouses are actually enjoying leisure jointly when $Z_{s}^{J}=1$ is not clear. It might well be that one partner is out carousing while the other is at home; perhaps they are both home in separate parts of the house; or perhaps they are together physically but not engaged in the same activity (Larson and Richards 1994, Chapt. 5). The data do not allow us to distinguish these possi- 


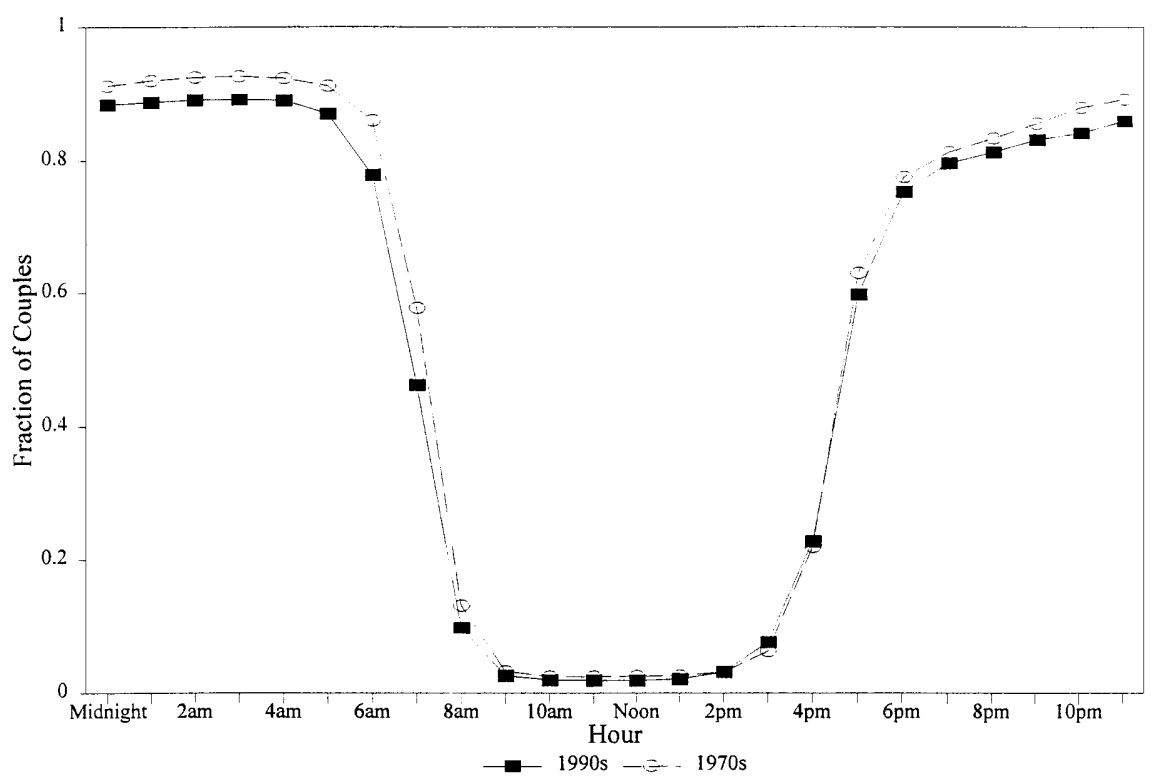

Fig. 4. Fraction of working couples at leisure, 1970s and 1990s

bilities. All we can do with these, the only available data that meet the criteria for sample size, is to examine the amount of time that the spouses could be together.

The indicator $Z_{s}^{J}$ shows whether both partners are away from work (and thus have the possibility of consuming leisure jointly) at the same hour of the day. Figure 4 graphs this measure for the 1970s and 1990s samples. Not surprisingly, given the paucity of evening and night work, the average $Z_{s}^{J}$ approaches one at those times of the day. What is interesting in the figure is how low $Z_{s}^{J}$ is at the prime working times of the day among working couples. Very clearly, most members of such couples are either working at roughly the same time, or are away from work, and thus possibly consuming leisure jointly, at the same time. The figure also makes it clear that the possibility for joint leisure decreased over the two-decade interval between the samples, a substantial and statistically significant decline in the total amount of joint leisure of 0.67 hours $($ s.e. $=0.07)$. This change is the clear result of the increase in average hours of market work among working spouses.

While Fig. 4 is interesting, it merely shows that there is substantial overlap in men's and women's timing of leisure. It says nothing about whether the overlap in spouses' leisure is any different from what would be observed if we generated such measures artificially by creating pairs of randomly matched men and women. To test for the existence of jointness we need to show that the actual distribution of work timing is different from what it would be if spouses' work timing were independent. If it were independent at hour $s$, the fraction of couples with both spouses enjoying leisure would then just be the product of the mean fractions of husbands and wives not working, $\hat{Z}_{s}^{J}=\left[1-L_{s}^{M}\right]\left[1-L_{s}^{F}\right]$.

To save space, in Table 3 I list the values of the differences $Z_{s}^{J}-\hat{Z}_{s}^{J}$ for selected hours only, for the 8353 couples in the 1970s sample and the 4003 
Table 3. Differences, actual - predicted jointness of leisure timing among working couples, CPS samples 1973-1978, and 1991 and $1997^{\mathrm{a}}$

\begin{tabular}{lcc}
\hline Hour: & \multicolumn{2}{c}{ Year } \\
\cline { 2 - 3 } & $1970 \mathrm{~s}$ & $1990 \mathrm{~s}$ \\
\hline Midnight & 0.0016 & 0.0059 \\
& $(0.48)$ & $(1.09)$ \\
3AM & 0.0002 & 0.0051 \\
& $(0.08)$ & $(0.97)$ \\
$6 \mathrm{AM}$ & 0.0060 & 0.0075 \\
& $(1.46)$ & $(1.03)$ \\
9AM & 0.0090 & 0.0065 \\
& $(1.62)$ & $(0.84)$ \\
Noon & 0.0100 & 0.0062 \\
& $(1.98)$ & $(0.88)$ \\
3PM & 0.0137 & 0.0169 \\
& $(2.14)$ & $(1.76)$ \\
6PM & 0.0064 & 0.0101 \\
& $(1.27)$ & $(1.31)$ \\
9PM & 0.0070 & 0.85 \\
& $(1.67)$ & $(1.31)$ \\
$N$ & 8353 & 4003 \\
\hline
\end{tabular}

${ }^{\text {a }} t$-statistics in parentheses below the differences.

couples in the 1990s. As in Fig. 4, all the differences are shown as fractions. These are quite small, but all are positive and thus consistent with a demand for jointness of leisure. Moreover, and despite the relatively small samples, at many hours of the day the hypothesis that we can predict the fraction of couples in which both spouses are at work knowing only the fraction of men and women generally who are at work at that hour is rejected with at least some degree of confidence. At times when most market work is accomplished in the United States, if one spouse is at not at work the other spouse is disproportionately likely not to be at work too.

This evidence suggests that couples attempt to time their market work to provide themselves the opportunity to be together when they are not working. If, however, jointness is something that people desire, we should observe that couples with higher full incomes consume more of it - jointness should be a normal good. To examine this idea, for working couples with each spouse usually working at least 6 hours per day (implicitly at least 30 hours per week) I estimate the impact on $Z_{s}^{J}$ of each spouse's earnings, holding constant each spouse's hours of market work and demographic characteristics. ${ }^{4}$ I thus focus on the relative impacts of the full earnings of the husband and wife on their joint timing of work.

The estimates are presented in Table 4, with Columns (2) and (6) showing the basic results. ${ }^{5}$ Before examining the impacts of earnings, consider the effects of extra hours of work on hours of joint leisure. The sum of the impacts of a one-unit increase in each of the spouses' workhours on their joint leisure time is $\left[\partial Z_{s}^{J} / \partial H^{M}+\partial Z_{s}^{J} / \partial H^{F}\right]$. This sum exceeds one in absolute value in both sets of data, suggesting that the spouses are unable to time marginal increases in market work in perfect synchrony. It is also interesting to note that in both samples $\partial Z_{s}^{J} / \partial H^{M}$ is essentially equal to $\partial Z_{s}^{J} / \partial H^{F}$ - jointness is reduced as 
Table 4. Determinants of hours of joint leisure time, full-time working couples, 1973-1978, 1991 and $1997^{\mathrm{a}}$

\begin{tabular}{|c|c|c|c|c|c|c|c|c|}
\hline & \multicolumn{4}{|c|}{$1970 \mathrm{~s}$} & \multicolumn{4}{|c|}{$1990 \mathrm{~s}$} \\
\hline & $\begin{array}{l}\text { Mean } \\
\text { (s.d. of } \\
\text { means) }\end{array}$ & (2) & (3) & (4) & $\begin{array}{l}\text { Mean } \\
\text { (s.d. of } \\
\text { means) }\end{array}$ & (6) & (7) & (8) \\
\hline$H^{M}$ & $\begin{array}{c}9.107 \\
(0.016)\end{array}$ & $\begin{array}{c}-0.538 \\
(0.022)\end{array}$ & $\begin{array}{r}-0.544 \\
(0.022)\end{array}$ & $\begin{array}{c}-0.564 \\
(0.022)\end{array}$ & $\begin{array}{c}9.530 \\
(0.042)\end{array}$ & $\begin{array}{r}-0.698 \\
(0.018)\end{array}$ & $\begin{array}{c}-0.699 \\
(0.018)\end{array}$ & $\begin{array}{r}-0.695 \\
(0.018)\end{array}$ \\
\hline$H^{F}$ & $\begin{array}{c}8.443 \\
(0.017)\end{array}$ & $\begin{array}{r}-0.597 \\
(0.021)\end{array}$ & $\begin{array}{c}-0.597 \\
(0.021)\end{array}$ & $\begin{array}{c}-0.601 \\
(0.021)\end{array}$ & $\begin{array}{c}8.851 \\
(0.039)\end{array}$ & $\begin{array}{r}-0.700 \\
(0.019)\end{array}$ & $\begin{array}{c}-0.699 \\
(0.019)\end{array}$ & $\begin{array}{r}-0.701 \\
(0.019)\end{array}$ \\
\hline$w^{M} / 100$ & $\begin{array}{c}2.689 \\
(0.016)\end{array}$ & $\begin{array}{c}0.064 \\
(0.023) \\
{[0.013]}\end{array}$ & $\begin{array}{c}0.132 \\
(0.018)\end{array}$ & $\begin{array}{c}0.076 \\
(0.023) \\
{[0.016]}\end{array}$ & $\begin{array}{c}6.720 \\
(0.072)\end{array}$ & $\begin{array}{c}0.055 \\
(0.011) \\
{[0.030]}\end{array}$ & $\begin{array}{c}0.064 \\
(0.008)\end{array}$ & $\begin{array}{c}0.058 \\
(0.011) \\
{[0.031]}\end{array}$ \\
\hline$w^{F} / 100$ & $\begin{array}{c}1.462 \\
(0.010)\end{array}$ & $\begin{array}{c}0.276 \\
(0.037) \\
{[0.031]}\end{array}$ & $\begin{array}{c}0.132 \\
(0.018)\end{array}$ & $\begin{array}{c}0.237 \\
(0.037) \\
{[0.026]}\end{array}$ & $\begin{array}{c}4.487 \\
(0.049)\end{array}$ & $\begin{array}{c}0.079 \\
(0.016) \\
{[0.028]}\end{array}$ & $\begin{array}{c}0.064 \\
(0.008)\end{array}$ & $\begin{array}{c}0.064 \\
(0.016) \\
{[0.023]}\end{array}$ \\
\hline$\tilde{Z}^{J}$ & $\begin{array}{l}13.161 \\
(0.033)\end{array}$ & & & & $\begin{array}{l}12.487 \\
(0.061)\end{array}$ & & & \\
\hline $\begin{array}{l}\text { Industry } \\
\text { controls }\end{array}$ & & No & No & Yes & & No & No & Yes \\
\hline $\begin{array}{l}\text { Adjusted } R^{2} \\
N\end{array}$ & & 0.191 & $\begin{array}{l}0.188 \\
7129\end{array}$ & 0.207 & & 0.494 & $\begin{array}{l}0.494 \\
3605\end{array}$ & 0.505 \\
\hline
\end{tabular}

a The samples include all couples with each spouse working at least 6 hours per day (implicitly at least 30 hours per week). Each equation also includes continuous measures of each spouse's age and indicators of each spouse's race and ethnicity, location, and calendar year. Estimated elasticities are in brackets.

much by an increase in the wife's market work as by an equal increase in the husband's, even though working wives spend fewer hours in the labor market than their husbands.

The most important result in this table is the estimated impact of each spouse's earnings, which, since the workhours of each are held constant, can be viewed as the spouses' full earnings. I thus interpret the coefficients (and the bracketed elasticities) on $w^{M}$ and $w^{F}$ in Columns (2) and (6) of Table 4 as partly reflecting income effects: With higher full earnings the spouses will be better able to indulge their desire for joint leisure. Jointness may also have a price in terms of a lower hourly wage that one spouse might receive because he/she chooses to consume leisure at the same time as his/her spouse, and this means that the estimated $\partial Z_{s}^{J} / \partial w^{j}$ also reflect a negative price effect. With this interpretation the parameter estimates imply that the income effect dominates any price effect. The elasticities are not large $(0.013$ for husbands, 0.031 for wives in the $1970 \mathrm{~s}, 0.030$ for husbands and 0.028 for wives in 1991), but they are significantly positive. ${ }^{6}$

There is no reason to believe that the price effects on the demand for jointness by the two spouses differ for equal increases in each $w^{j}$. We can interpret the relative magnitudes of the estimated $\partial Z_{s}^{J} / \partial w^{j}$ as reflecting how equal increases in each spouse's full earnings affect the couple's demand for jointness at constant prices. The equations presented in Columns (3) and (7) of Table 4 constrain the effects of the husband's and wife's earnings on their joint leisure to be identical. This constraint is soundly rejected for the 1970s sample: Raising 
the wife's earnings by one dollar has a larger effect on the jointness of their leisure than does raising the husband's. While evidence against the notion that couples pool their income is accumulating rapidly (Thomas 1994; Lundberg et al. 1997; Inchauste 1997), those studies all examine spending on items that might be viewed as specific to children. The evidence for the 1970s suggests that, even in their demand for an activity that is ipso facto joint, husbands and wives responded differently, so that a change in the relative earnings of the spouses affected the couple's consumption.

The result disappears in the data for the 1990s: The constraint implied in Column (7) cannot be rejected, and the elasticities in Column (6) are almost identical. Even though working wives in the 1990s sample still worked the same 0.7 hours less in the market per day than their husbands, an increase in their full earnings generated the same change in the couples' joint leisure as did an increase in their husbands' full earnings. Indeed, if we follow the literatures by assuming that hours supply elasticities are more positive for wives than for husbands (Pencavel 1986; Killingsworth and Heckman 1986), we can infer that by the 1990s the total effect (direct, and indirect through the spouses' total workhours) on $Z_{s}^{J}$ of an increase in the wife's full earnings was less positive than that of an increase in her husband's full earnings.

Unless one believes that the relative price of jointness in response to higher women's wages fell over the twenty-year period, the equalization of the responses to husbands' and wives' full earnings might suggest that men's preferences for joint leisure rose to equal those of their working spouses. Alternatively, the extent of marital sorting along the dimension of preferences for jointness may have changed over this twenty-year period in such a way as to alter the mix of married couples in these CPS samples. Without much additional information we cannot distinguish between these possibilities, or between them and others. ${ }^{7}$

Columns (4) and (8) of Table 4 include one-digit indicators of industry affiliation for both husband and wife. Although their inclusion does not stem from the consumer model in (6) and (7), one might view them as testing whether any correlated demand-side constraints could be generating the results. Alternatively, their inclusion may allow us to account for possible discrimination in the kinds of work environments available to women. Regardless, the estimated effects of both the $H^{j}$ and the $w^{j}$ do not change qualitatively from the basic estimates in Columns (2) and (6).

The evidence in this section suggests strongly that the subfunction $U^{J}$ in (6) is not identically zero. The most appropriate notion of complementarity in the context of time use is as an instantaneous phenomenon: Is spouses' time used in such a way as to indicate that they are better off having the opportunity to consume leisure together? Examining their instantaneous use of time, we can infer that their time use is complementary in this sense. A desire for togetherness is implicit in couples' decisions about the timing of each spouse's supply of effort to the labor market; and couples use some of their income to purchase the "good," synchronous leisure.

\section{The longest day}

An immense literature has tried to isolate the effects of exogenous increases in monetary wealth on consumption, labor supply and other life-cycle choices 
(e.g., efforts such as Holtz-Eakin et al. 1993, and Imbens et al. 1999). Exogenous increases in the other component of full income, the amount of time at the worker-consumer's disposal, have been investigated much more rarely. I am aware only of one attempt (Hamermesh 1984) that examined the responses of consumption and labor supply to exogenous differences in time endowments in the form of greater expected longevity, and one other (summarized in Biddle and Hamermesh 1990) in which people offered subjective responses about how they would spend a hypothetical increase in their endowment of time.

There is clearly room for interesting empirical research here. One can imagine, for examples, examining behavior after such unusual (and often depressing) cases as surprising cures from or diagnoses of usually fatal diseases, lateterm miscarriages or stillbirths, prison early-release programs, and others. The difficulty, of course, is that data on these events and on the consumption-leisure choices of their victims or beneficiaries are difficult to come by.

There is one exogenous, albeit completely foreknown event that affects residents of most industrialized societies - the annual loss of one hour on a Sunday early in spring and the gain of one hour on a Sunday early in autumn. While this is not a perfect natural experiment - it is hardly unexpected - it provides a rare opportunity to examine how people respond to a truly exogenous change in their endowment of time. The data set that provides this opportunity is the Dutch Tijdbestedingsonderzoek of 1990, a time-budget study of over 3000 individuals ages 12 and up. Each respondent maintained a diary of his/her activities that he/she filled out for the previous day each morning. The diaries were kept for seven days, Sunday through Saturday. The list of activities was subsequently coded into over 200 categories, and the data are presented showing each person's activities for each of 96 quarter-hours on each of the seven sampled days.

Half the sample kept diaries for a week in early October of 1990; the other half sample kept diaries for the week before that, the Sunday of which included the day that the Netherlands went back on winter time. Thus for half the sample a diary is kept for a day on which each person's time endowment increased by 60 minutes. I include in the analysis all respondents ages 18 through 70; and, because the average respondent engaged in only 16 different activities per day (Gronau and Hamermesh 2001) and because of space constraints, I aggregate activities into twelve major categories.

For each activity a I estimate:

$$
\begin{aligned}
T_{a}= & \alpha_{a 1} X+\alpha_{a 2} S U N D A Y+\alpha_{a 3} L O N G+\alpha_{a 4} S U N D A Y \bullet L O N G+\varepsilon_{i}, \\
& a=1, \ldots, 12
\end{aligned}
$$

where $T_{a}$ is the time spent on that activity on a particular day; $X$ is a vector of control variables including education indicators, a quadratic in age, the number of children and indicators of their ages; $L O N G$ is an indicator equaling one for those respondents whose diaries cover the week including the return to winter time; and the $\alpha_{a i}$ are parameters to be estimated. Estimates of the $\alpha_{a 4}$ show how the extra hour on that Sunday is spent and are essentially double differences in time use that compare behavior on Sunday by the half-sample interviewed during the long week to their behavior on other days, relative to the same difference in the other half-sample. 
Table 5. Extra minutes by activity on winter-time day, the Netherlands, $1990^{\mathrm{a}}$

\begin{tabular}{lccccc}
\hline & \multicolumn{2}{c}{ Men } & & \multicolumn{2}{c}{ Women } \\
\cline { 2 - 3 } \cline { 5 - 6 } & Married & Unmarried & & Married & Unmarried \\
\hline Cleaning and cooking & -0.65 & -4.26 & & 0.45 & 8.7 \\
Eating & $(8.67)$ & $(14.86)$ & & $(7.39)$ & $(12.51)$ \\
& 1.04 & 9.97 & -3.39 & -4.50 \\
Family care & $(4.80)$ & $(8.57)$ & & $(3.60)$ & $(7.70)$ \\
& -0.49 & -1.42 & & 1.44 & -0.14 \\
Other personal activities & $(3.44)$ & $(3.26)$ & & $(4.61)$ & $(5.83)$ \\
& 5.09 & -8.42 & & 2.73 & -1.55 \\
Organized activities & $(2.84)$ & $(8.19)$ & & $(2.21)$ & $(4.43)$ \\
& 2.16 & 2.13 & & -6.23 & 6.65 \\
Radio and TV & $(5.72)$ & $(8.91)$ & & $(3.87)$ & $(8.71)$ \\
& 11.42 & 36.82 & & -1.42 & 1.66 \\
Reading and writing & $(8.31)$ & $(19.63)$ & & $(5.54)$ & $(11.68)$ \\
& 1.01 & -9.05 & & -1.41 & 7.06 \\
Schooling and training & $(5.04)$ & $(11.26)$ & & $(3.89)$ & $(8.07)$ \\
Shopping & 2.80 & -11.33 & & -0.91 & -0.19 \\
& $(4.38)$ & $(10.34)$ & & $(3.20)$ & $(7.23)$ \\
Sleeping & 3.45 & -14.66 & & -2.13 & -0.93 \\
Sports and leisure & $(4.93)$ & $(13.55)$ & & $(4.03)$ & $(7.45)$ \\
& 43.32 & 27.61 & & 52.92 & 41.38 \\
Work in the market & $(7.48)$ & $(16.15)$ & & $(6.39)$ & $(12.78)$ \\
& -25.64 & 45.15 & 18.76 & 11.24 \\
$N$ & $(12.67)$ & $(28.51)$ & $(10.23)$ & $(19.53)$ \\
& 26.66 & -12.54 & -0.80 & -9.39 \\
& $(18.79)$ & $(38.61)$ & $(10.33)$ & $(22.51)$ \\
& 862 & 308 & 1315 & 494 \\
\hline
\end{tabular}

${ }^{a}$ Each equation also includes measures of education, age, and the number of children and their ages.

Before considering the estimates of (8) it is crucial to be clear what the equation does not necessarily show. First, the results describe behavior on a Sunday, a day in which, especially in the Netherlands in 1990, market work was a quite unusual phenomenon even among workers classified as full-time. Also, and most important, while I do not expect that people adjusted to the impending "gain" of one hour over the entire six months since the country "lost" an hour in the previous spring, it is possible that some respondents adjusted by altering their behavior on the Saturday before the "gain" of one hour. (For example, some people, including this author, may set their clocks back on the Saturday before standard time begins.) Thus to the extent that people preadjust their behavior and take account of the future exogenous increase in their time endowments, our estimates will fail to depict the full set of responses to this temporary increase in full incomes.

With these caveats in mind, consider the estimates of (8) that are presented by marital status for men and women separately in Table 5 . These are least-squares regression coefficients that do not account for the substantial left-censoring that occurs in many of activities. I present them for ease of interpretation and because the tobit estimates of the equations yield results that are qualitatively identical. The extra hour that is gained when the country went on standard time is used overwhelmingly for additional sleep. 
Table 6. Extra minutes by activity on winter-time day, the Netherlands, 1990, married by presence of young children

\begin{tabular}{|c|c|c|c|c|}
\hline & \multicolumn{2}{|c|}{ Men } & \multicolumn{2}{|c|}{ Women } \\
\hline & $\begin{array}{l}\text { No children } \\
\text { under } 13\end{array}$ & $\begin{array}{l}\text { Children } \\
\text { under } 13\end{array}$ & $\begin{array}{l}\text { No Children } \\
\text { under } 13\end{array}$ & $\begin{array}{l}\text { Children } \\
\text { under } 13\end{array}$ \\
\hline \multirow[t]{2}{*}{ Cleaning and cooking } & 4.00 & -3.10 & 1.91 & -1.88 \\
\hline & $(10.88)$ & $(13.15)$ & $(9.73)$ & $(10.48)$ \\
\hline \multirow[t]{2}{*}{ Eating } & 4.51 & -2.60 & -2.51 & -4.83 \\
\hline & $(6.03)$ & $(7.29)$ & $(4.74)$ & $(5.11)$ \\
\hline \multirow[t]{2}{*}{ Family care } & -2.48 & 6.05 & 0.82 & 1.42 \\
\hline & $(4.30)$ & $(5.20)$ & $(6.08)$ & $(6.55)$ \\
\hline \multirow[t]{2}{*}{ Other personal activities } & -3.45 & -7.21 & 3.76 & 1.66 \\
\hline & $(3.57)$ & $(4.31)$ & $(2.91)$ & $(3.13)$ \\
\hline \multirow[t]{2}{*}{ Organized activities } & 0.13 & 6.85 & -5.20 & -7.23 \\
\hline & $(7.18)$ & $(8.68)$ & $(5.10)$ & $(5.50)$ \\
\hline \multirow[t]{2}{*}{ Radio and TV } & 14.05 & 9.02 & -17.57 & 17.28 \\
\hline & $(10.44)$ & $(12.63)$ & $(7.30)$ & $(7.86)$ \\
\hline \multirow[t]{2}{*}{ Reading and writing } & 4.33 & -2.73 & 0.08 & -4.16 \\
\hline & $(6.33)$ & $(7.66)$ & $(5.12)$ & $(5.51)$ \\
\hline \multirow[t]{2}{*}{ Schooling and training } & 6.23 & -2.52 & 0.77 & -3.06 \\
\hline & $(5.51)$ & $(6.66)$ & $(4.22)$ & $(7.31)$ \\
\hline \multirow[t]{2}{*}{ Shopping } & 3.64 & 4.98 & -3.58 & -0.88 \\
\hline & $(6.19)$ & $(7.49)$ & $(5.30)$ & $(5.71)$ \\
\hline \multirow[t]{2}{*}{ Sleeping } & 45.01 & 44.67 & 47.48 & 59.88 \\
\hline & $(9.40)$ & $(11.36)$ & $(8.42)$ & $(9.07)$ \\
\hline \multirow[t]{2}{*}{ Sports and leisure } & -46.27 & 9.05 & 31.50 & 3.48 \\
\hline & (15.91) & (19.24) & $(13.47)$ & $(14.51)$ \\
\hline \multirow[t]{2}{*}{ Work in the market } & 30.30 & -2.48 & 2.53 & -1.68 \\
\hline & $(23.49)$ & $(28.40)$ & $(13.60)$ & $(14.65)$ \\
\hline$N$ & 519 & 343 & 710 & 605 \\
\hline
\end{tabular}

Indeed, the only group for which sleep accounts for less than half of the extra hour is unmarried men. Among this group the extra time is used for sports/leisure and radio/TV watching more than for additional sleep (on this Sunday). ${ }^{8}$

A bit more can be learned by disaggregating married men and women, the large majority of the sample, by the presence of young (under age 13) children. These results of this disaggregation are shown in Table 6. Quite remarkably, and unlike the other three groups, married women with young children "spend" the extra hour entirely on extra sleep, corroborating at the margin the results in Biddle and Hamermesh (1990) for this group on average. Very little else in these regressions is statistically significant, except for the decline in sports/ leisure time among husbands without young children and the increase in this same category among wives without young children. The source of these latter effects is absolutely unclear.

The essential result of this little exercise is that the large majority of the exogenous increase in time that occurs every autumn is used for sleep. This marginal effect far exceeds the average propensity to spend time on sleep of roughly $1 / 3$. The short-run full-income elasticity at the margin on Sundays through an increase in the endowment of time is very high for sleep, but quite low for all other activities. 


\section{Conclusions and new directions}

The results make several new facts clear. Between 1973 and 1997 the burden of inequality in the job disamenity, working at a generally unpleasant time of day, appears to have shifted in the same direction as the burden of earnings inequality. This suggests that measures of changes in earnings inequality understate the extent of change in inequality in the overall returns to market work. There is clear evidence that couples arrange their work schedules to allow time for leisure that they consume jointly. Moreover, the demand for joint leisure is not inferior - all else equal, those couples with higher earning capacities enjoy more of it. Finally, an expected windfall of time, the one-hour gain that occurs every autumn when clocks are turned back to standard time, is consumed mainly as sleep, especially by married women with young children.

These few examples here have been designed to demonstrate that there are many potential avenues for learning about time use beyond the standard ones of examining weekly or other aggregations of reported hours of work. There are some cases, such as issues of spouses' togetherness, where going beyond standard analyses is the only way to understand the underlying behavior. There are others where this approach can generate tests of ideas examined in other contexts, such as markets for amenities, economic inequality, and power relationships within households, that may expand upon and possibly surpass conventional approaches in their ability to allow us to understand behavior.

\section{Endnotes}

1 At least through 1991 these changes occurred independently of any changes in demographics or in the distribution of workers across one-digit industries or occupations (Hamermesh 1999b).

2 I multiply top-coded earnings by 1.5 , as is common in this literature. Unlike the literature on earnings inequality, which compares earnings across points in the distribution, these calculations are based on averages across workers in different quartiles. This is done for comparison purposes to the distribution of work timing: It would make no sense to compare work histories of those few individuals who happen to be at particular points in an earnings distribution.

${ }^{3}$ Individuals were matched as spouses based upon listing as household head or spouse and on line number (the person's position in the household) in the CPS records. Only people whose marital status was denoted as married, spouse present, are included in the match. Given the possibility that unmarried siblings are in the same residence, the data do not allow us to perform similar analyses for cohabiting unmarried couples.

${ }^{4}$ If we include all working couples the results are quite similar, except for a substantially lower coefficient on wife's hours. The same measures of the presence of children cannot be included for both samples, so that for purposes of comparability I exclude them in the Table. Nonetheless, when the equations for the 1970s and 1990s are expanded to include indicators of the presence of children and their ages, the conclusions about the impacts of hours and weekly earnings on jointness are unaffected.

5 A regional difference exists in the demand for jointness. In the "Rust Belt," defined here as the New England, Mid-Atlantic and East North Central subregions, joint leisure was a significant 0.4 hours per day lower in both the 1970s and the 1990s than in the rest of the United States among otherwise identical couples. Whether this reflects differences in tastes or differences in the (unmeasured) constraints on couples' choices is not clear.

${ }^{6}$ An additional test of the validity of this approach asks how well one could have predicted $Z_{90 s}^{J}$ with knowledge of the structure of the relationship in the 1970s and the means of the determinants of $Z_{90 s}^{J}$. Using the PCE deflator to adjust 1990s wages, and the coefficients in Columns (2) and (6), this decomposition shows that only $26 \%$ of the change in $Z^{J}$ between the 1970 s and the 1990s was explicable by changes in the independent variables. Most of the change resulted from changes in the coefficients. 
7 Among married couples under age 60, in the 1970s the likelihood that both spouses were working was lower than in the 1990s. This selectivity (of wives into the work force) may affect our results, but the direction of any bias is unclear, as it depends on the nature of the selectivity. This is not chiefly an issue of wives' market wages, since we hold those constant. One reasonable possibility is that wives who worked in the 1970s had relatively more power compared to their husbands than wives in the 1990s. If so, accounting for this change in selectivity would strengthen the inference that husbands' and wives' preferences for joint leisure converged over this time interval.

8 The data set regrettably contains no information on individuals' wage rates, but it does have information on the household's net income. I included this variable in reestimates of the equations presented here, with little change in the estimated $\alpha_{a i}$.

\section{References}

Becker G (1965) A Theory of the Allocation of Time. Economic Journal 75(3):493-517

Berman E, Bound J, Machin S (1998) Implications of Skill-Biased Technological Change: International Evidence. Quarterly Journal of Economics 113(4):1245-1280

Biddle J, Hamermesh D (1990) Sleep and the Allocation of Time. Journal of Political Economy 98(5):922-943

Boskin M, Dulberger E, Gordon R, Griliches Z, Jorgenson D (1998) Consumer Prices, the Consumer Price Index, and the Cost of Living. Journal of Economic Perspectives 12(1):3-26

Gronau R, Hamermesh D (2001) The Demand for Variety: A Household Production Perspective. National Bureau of Economic Research, Working Paper No. 8509, October

Hamermesh D (1984) Life Cycle Effects on Consumption and Retirement. Journal of Labor Economics 2(3):353-370

Hamermesh D (1996) Workdays, Workhours and Work Schedules: Evidence for the United States and Germany. The W.E. Upjohn Institute, Kalamazoo, MI

Hamermesh D (1999a) The Timing of Work Over Time. Economic Journal 109(1):37-66

Hamermesh D (1999b) Changing Inequality in Markets for Workplace Amenities. Quarterly Journal of Economics 114(4):1085-1123

Holtz-Eakin D, Joulfaian D, Rosen H (1993) The Carnegie Conjecture: Some Empirical Evidence. Quarterly Journal of Economics 108(2):413-435

Imbens G, Rubin D, Sacerdote B (1999) Estimating the Effects of Unearned Income on Labor Supply, Earnings, Savings, and Consumption: Evidence from a Survey of Lottery Players. National Bureau of Economic Research, Working Paper No. 7001, March

Inchauste G (1997) Education, Labor Supply, and Household Expenditures in Bolivia. Unpublished Ph.D. dissertation, University of Texas

Juhn C, Murphy KM, Topel R (1991) Why Has the Natural Rate of Unemployment Increased over Time? Brookings Papers on Economic Activity (2):75-142

Juhn C, Murphy KM, Pierce B (1993) Wage inequality and the rise in returns to skill. Journal of Political Economy 101(3):410-442

Killingsworth M, Heckman J (1986) Female Labor Supply: A Survey. In: Ashenfelter O, Layard R (eds) Handbook of Labor Economics. North-Holland, Amsterdam, 103-204

Kostiuk P (1990) Compensating Differentials for Shift Work. Journal of Political Economy 98(5):1054-1075

Larson R, Richards M (1994) Divergent Realities: The Emotional Lives of Mothers, Fathers, and Adolescents. Basic Books, New York

Leamer E (1996) Wage Inequality from International Competition and Technological Change: Theory and Country Experience. American Economic Review 86(2):309-314

Lundberg S, Pollak R, Wales T (1997) Do Husbands and Wives Pool their Resources? Evidence from the U.K. Child Benefit. Journal of Human Resources 32(3):463-480

Mellor E (1986) Shift Work and Flexible Time: How Prevalent Are They? Monthly Labor Review 109(11):14-21

Pereira PT, Martins PS (2000) Does Education Reduce Wage Inequality: Evidence from Fifteen European Countries. Institute for the Study of Labor (IZA), Working Paper No. 120, Bonn, February

Pencavel J (1986) Labor Supply of Men: A Survey. In: Ashenfelter O, Layard R (eds) Handbook of Labor Economics. North-Holland, Amsterdam, 3-102 
Rosen S (1974) Hedonic Prices and Implicit Markets. Journal of Political Economy 82(1):34-55

Stafford F (1986) Forestalling the Demise of Empirical Economics: The Role of Microdata in Labor Economics Research. In: Ashenfelter O, Layard R (eds) Handbook of Labor Economics. North-Holland, Amsterdam, 387-423

Thomas D (1994) Like Father, Like Son: Like Mother, Like Daughter: Parental Resources and Child Height. Journal of Human Resources 29(1):950-988

Woodbury S, Hamermesh D (1992) Taxes, Fringe Benefits and Faculty. Review of Economics and Statistics 84(2):287-296 